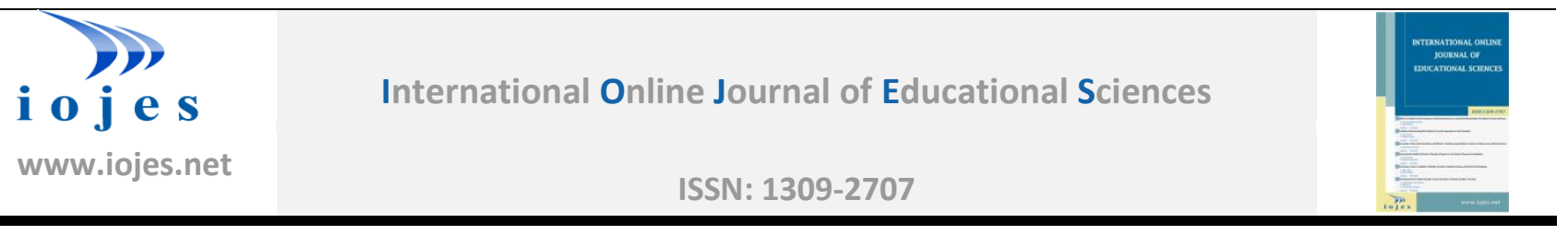

\title{
Digital Literacy Status of Turkish Teachers
}

\author{
Research Article
}

\author{
Sedat EROL ${ }^{1}$, Erkan AYDIN² \\ ${ }^{1}$ Adryaman University, Faculty of Education, Department of Turkish Teaching, Adryaman, Turkey, ORCID: 0000-0003-0840-9903 \\ ${ }^{2}$ Ministry of National Education, Turkey, ORCID: 0000-0002-6452-6058
}

To cite this article: Erol, S., \& Aydin, E. (2021). Digital literacy status of Turkish teachers, International Online Journal of Educational Sciences, 13(2), 620-633.

\begin{abstract}
ARTICLE INFO
Article History:

Received: 05.10.2020

Available online:

14.03.2021

ABSTRACT

The aim of this study is to determine the digital literacy status of Turkish teachers and to examine them in terms of various variables. In line with this purpose, the digital literacy status of Turkish teachers was determined and examined whether these situations differ according to variables such as gender, age, years of service in the profession, technology usage level, daily time of internet usage, using distance education platforms and social media. Scanning model was used in the research. The “Digital Literacy Scale” which was developed by Ng (2012) and adapted by Hamutoğlu, Güngören, Uyanık and Erdoğan (2017) was used as the data collection tool. Study group of the research consist of 188 Turkish language teachers who work actively in public schools in Turkey. The data obtained from the Digital Literacy Scale in the research were analyzed with the SPSS 21 package program. As a result of the research, it was found that Turkish teachers' digital literacy levels are high; it was determined that digital literacy levels indicate significant differences according to variables of age, years of service in the profession, technology usage level, daily internet usage time, using distance education platforms and social media. The fact that digital literacy levels decline as participants' age and years of service increase and also those who have high digital literacy levels use distance education platforms and social media more effectively are important results of the research.
\end{abstract}

(C) 2021 IOJES. All rights reserved

Keywords:

Digital literacy, Turkish teacher, digital education

\section{Introduction}

Although the effects of digital technologies differ from one individual to another, in today's conditions, individuals are expected to make decisions, evaluate their decisions and take action using digital technologies (Selwyn \& Odabaşı, 2019: 1). Because the effective use of digital technologies contributes to individual life in many ways such as providing cognitive development, creating identity, providing fun time, providing non-

\footnotetext{
${ }^{1}$ Corresponding author's address: Adıyaman Üniversitesi Telephone: +905314075747

e-mail: sedaterol02@hotmail.com

DOI: https://doi.org/10.15345/iojes.2021.02.020
} 
spatial communication, providing access to rich resources, supporting career development (Campbell \& Akbulut, 2019: 89; Johnson, 2008; Johnson, 2010; Spears et al: 2012).

Digital elements, which are important factors in shaping the age we live in, have led to radical changes and transformations in educational environments. In flexible and independent learning environments where instant communication is established, there have been changes in the skills used by individuals, the scope of the skills has either expanded or new concepts have emerged. The concept of digital literacy is a concept that emerged due to these changes and is integrated with new generation learning environments.

Until half a century ago, when it comes to literacy the ability to understand and use printed and written materials in different fields came to mind. As, considering the opportunities of the period, materials such as books, newspapers, and magazines were used as source of messages. With the technological developments in the 21st century, important changes have occurred in the world of knowledge. The most important of these changes is the innovations seen in information sources (Kurt \& Orhan Göksun, 2020: 90). As a result of the possibilities offered by technology, reading and writing skills have been transferred from authentic materials such as books, newspapers and magazines to digital environments that also require technical skills. In this context, it can be stated that 21st century students are now digitally literate (Soylu Yilmaz \& Akkoyunlu, 2019: 152). As a matter of fact, in 21st century literacy, the importance of skills that require use of technology and media is increasing (Pilgrim \& Martinez, 2013: 60).

Digital literacy is a concept that is included in 21st century skills and its scope is expanding day by day. With the diversification of digital tools, the facilitation of the transfer of information and the widespread use of content creation, this skill has made interpersonal communication stronger (Kazakoff, 2014; Dowdall, 2009; Menzi Çetin \& Akkoyunlu, 2017: 111). In the transformation process, in which information transfer was diversified, opportunities for fast and immediate communication emerged.

The concept of digital literacy refers to a wider scope considering the technological possibilities used to receive and transmit information, with reading and writing skills at its centre. The American Library Association defines digital literacy as "the ability to use information and communication technologies to find, evaluate, create and communicate information requiring both cognitive and technical skills" (Heitin, 2016: 1). In another definition, it is expressed as the ability to find, evaluate, use, share and create content using information technologies and the internet. (Cited from Cornell University, 2009, Pilgrim \& Martinez, 2013: 64). Digital literacy is the ability to understand and use information from a wide variety of sources in a variety of formats. In this respect, you must not only have the ability find things but also the ability to use them (Jones \& Flannigan, 2006: 6). As along with the interpretation processes, digital literacy includes the ability to apply new knowledge.

Digital literacy consists of many components such as creativity, critical thinking and evaluation, cultural and social understanding, cooperation, finding and choosing information, and effective communication (Hague \& Fayton, 2010: 80). According to Ng (2012), digital literacy consists of three dimensions: cognitive, technical and social-emotional. The relationship among these dimensions is as follows:

The problem of the study should be clearly indicated in the Introduction part. Introduction part should be followed by method, findings, discussion and conclusion. The problem of the study should be clearly indicated in the Introduction part. Introduction part should be followed by method, findings, discussion and conclusion. The problem of the study should be clearly indicated in the Introduction part. Introduction part should be followed by method, findings, discussion and conclusion. 


\section{Can we teach digital natives digital literacy?}

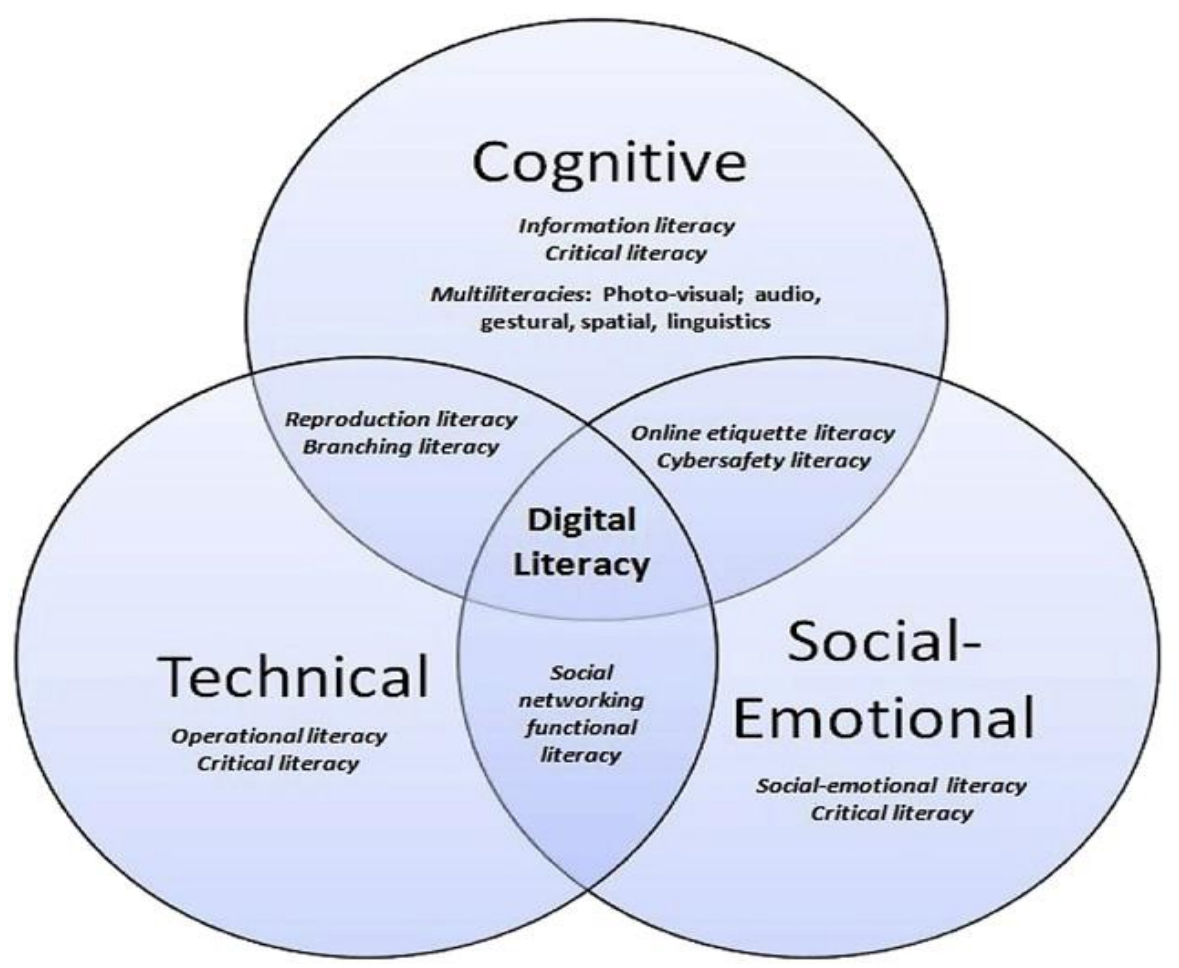

Figure 1. Digital literacy model (Ng, 2012).

Martin and Grudziecki (2006) discussed digital literacy in three stages. In the model based on cognition, functionality and creativity, digital literacy is defined as a transitional structure.

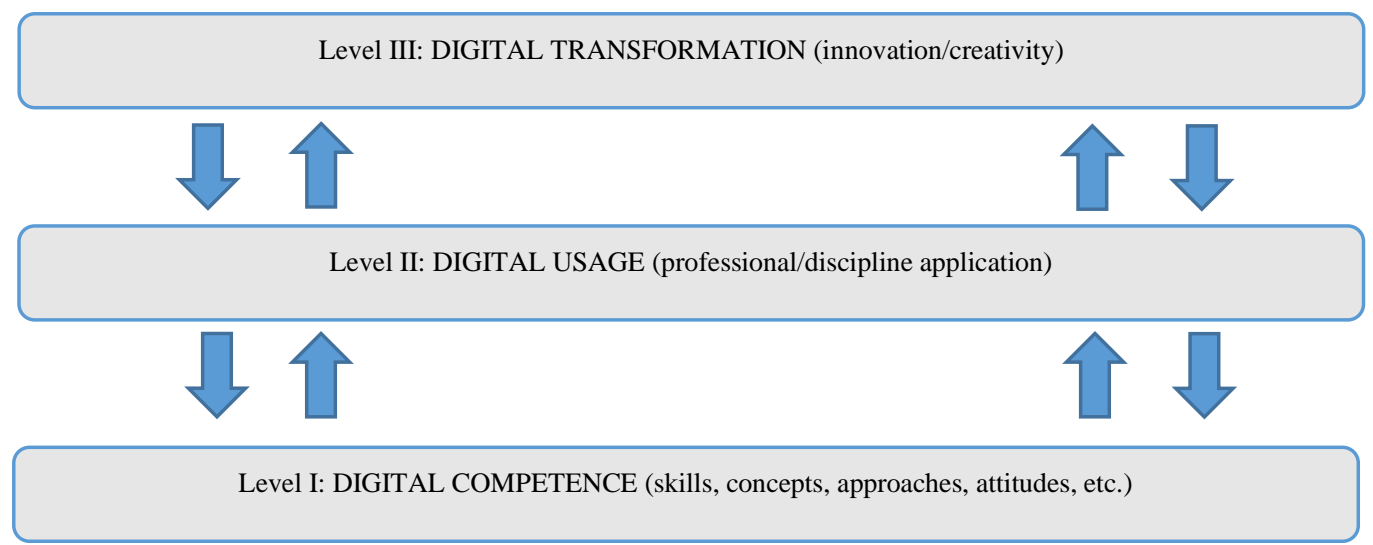

Figure 2. Levels of Digital Literacy

In the study titled The Project of Understanding and Developing Digital Competencies in Europe, five dimensions focusing on creativity and critical thinking were determined such as information, communication, content, security, and problem solving (Ferrrari, 2013).

In the changing, developing and transforming world, it is seen that digital experiences increase depending on the interests, desires and needs of students and the importance of digital platforms is felt in educational environments (Erol, 2020). In fact digital environments have become not only a tool in learning and teaching activities, but an important factor affecting the learning process (Kula \& Avc1, 2019: 262). In this digital transformation process, accessing and sharing information has radically changed and many elements, especially educational institutions, learning environments and materials used, have been affected by the process. Along with students, who are one of the major elements of education, teachers have deeply felt the 
digital transformation and they were shaped by the requirements of this age (Taşkıran, 2017; Parlak, 2017: 1742). As in these new generation learning environments, teachers have a great responsibility in educating students who are to meet the needs of the digital age (Gökbulut, 2019: 161).

When the literature on digital literacy is examined, it can be seen that studies were conducted regarding teacher candidates (Özoğlu, 2019; Sarıkaya, 2019; Özerbaş \& Kuralbayeva, 2018; Göldağ \& Kanat, 2018; Kozan, 2018; Üstündağ, Güneş \& Bahçivan, 2017; Çetin, 2016; Kazu \& Erten, 2014; İşçioğlu \& Kocakuşak, 2012; Kuşak, 2008). It was also determined that there are few studies (Korkmaz, 2020; Arslan, 2019; Öçal, 2017) conducted on teachers who play an important role in providing digital literacy skills, and no study was found regarding the digital literacy levels of Turkish teachers. Accordingly, in this research it was aimed to determine and examine the digital literacy levels of Turkish teachers according to different variables.

\section{The Purpose of the Research}

In this study, it was aimed to examine and evaluate the digital literacy levels of Turkish teachers according to different variables. In this context, the following questions were asked regarding the purpose of the study:

1. What is the digital literacy level of Turkish teachers?

2. Is there a difference in digital literacy status of Turkish teachers in terms of gender?

3. Is there a difference in digital literacy status of Turkish teachers in terms of age?

4. Is there a difference in digital literacy status of Turkish teachers in terms of years of service in the profession?

5. Is there a difference in digital literacy status of Turkish teachers in terms of using technology?

6. Is there any difference in digital literacy status of Turkish teachers according to the duration of internet use?

7. Is there a difference in digital literacy status of Turkish teachers in terms of using distance education platforms (EBA and others)?

8. Is there a difference in digital literacy status of Turkish teachers in terms of using social media in the distance education process?

\section{Methodology}

\section{Research Model}

The research was carried out with scanning model. This model is a research model that aims to determine a past or current situation as it exists (Karasar, 2018: 109). In this model, it is provided to identify and describe the tendencies, attitudes or views across the universe through studies on a sample selected from a universe. The researcher makes inferences about the universe based on the data obtained from the sample (Creswell, 2017: 155-156). The data obtained from the research was collected via Google Forms.

In order to carry out the study, the ethics committee permission was obtained from the Provincial Directorate of National Education affiliated to the Adiyaman Provincial Governorship in line with the decision dated 17/06/2020, numbered 12705949 and issued 8001623, by the Adryaman Governorship Provincial Ethics Commission. 


\section{Study Group}

The study group of the research consists of totally 188 Turkish teachers, 80 female and 108 male, working for the Ministry of National Education. In order to determine the sample of the study, convenience sampling, which is one of the purposeful sampling methods, was preferred (Yıldırım \& Şimşek, 2008).

\section{Data Gathering Tool}

The data of the study were collected via the "Digital Literacy Scale" which was developed by Ng (2012) and adapted to Turkish by Hamutoğlu, Güngören, Uyanık and Erdoğan (2017). The scale consists of 17 items and has four sub-dimensions: "attitude, technical, cognitive and social". There are 7 items in the attitude subdimension, 6 in the technical sub-dimension, 2 items in the cognitive sub-dimension and 2 items in the social sub-dimension. There are no negative items in the scale which consists of 5-point Likert type as Agree / Disagree. During the adaptation of the scale to Turkish, a linguistic equivalence study was carried out. Exploratory and confirmatory factor analyzes were carried out considering the construct validity of the scale. $\mathrm{KMO}$ and Barlett values were examined in the exploratory factor analysis. In this context, KMO coefficient was calculated as .91 and Barlett Sphericity test value was found as $1549.40(\mathrm{p}<.01$, sd = 136). By conducting the confirmatory factor analysis, the fit index values of the scale were calculated as RMSEA $=.071, \mathrm{GFI}=.93$, $\mathrm{AGFI}=.91, \mathrm{CFI}=.98, \mathrm{NFI}=.96, \mathrm{NNFI}=.97$ and $\mathrm{SRMR}=.05$. In addition, the internal consistency or reliability coefficient of the scale was calculated as .93 .

\section{Data Analysis}

The data obtained from the Digital Literacy Scale in the research were analyzed with the SPSS 21 package program. First of all, descriptive analysis of the obtained data, that is, the total scores of the scale and the scores obtained from the sub-dimensions were calculated and the mean scores, standard deviations, skewness and kurtosis values were examined. The t-test was conducted in the analysis of the data obtained for two independent groups. In the analysis of the data obtained for more than two groups, Kruskal-Wallis and one-way variance (ANOVA) analysis were performed. The reason for the Kruskal-Wallis analysis is that the homogeneity of variances is not provided in the one-way variance (ANOVA) analysis. In addition, after the Kruskal-Wallis and ANOVA tests, the Games-Howell test and the Scheffe test of the Post Hoc tests were utilized to understand the significance relationship between the groups.

\section{Findings and Comments}

In this section, findings and comments regarding the research questions are included. In this context, the descriptive statistics of the digital literacy status of Turkish teachers are included in Table 1.

Table 1. Score Averages of Turkish Teachers' Digital Literacy Status

\begin{tabular}{|c|c|c|c|c|c|c|c|c|c|}
\hline & $\mathbf{n}$ & Min. & Max. & Range & Ort. & Ss & Skewness & Kurtosis & $\begin{array}{l}\text { Cronbach's } \\
\text { Alpha }\end{array}$ \\
\hline Attitude & 188 & 9 & 35 & $7-35$ & 27,04 & 5,560 &,- 895 & ,537 & .883 \\
\hline Technical & 188 & 8 & 30 & $6-30$ & 22,63 & 4,826 &,- 734 & ,391 & .904 \\
\hline Cognitive & 188 & 4 & 10 & $2-10$ & 8,06 & 1,538 &,- 482 &,- 331 & .746 \\
\hline Social & 188 & 3 & 10 & $2-10$ & 6,94 & 1,780 &,- 187 &,- 324 & .728 \\
\hline $\begin{array}{l}\text { Digital Literacy } \\
\text { Total Score }\end{array}$ & 188 & 24 & 85 & $17-85$ & 64,67 & 11,823 &,- 664 & 409 & .935 \\
\hline
\end{tabular}

When Table 1 is examined, it can be seen that 188 Turkish teachers participated in the study. Teachers can score 17 at least from the digital literacy scale, and the highest score they can take is 85 . The digital literacy scale has 4 different sub-dimensions: attitude, technical, cognitive and social. It was determined that teachers take $X=27.04$ from the attitude dimension of the digital literacy scale, $X=22.63$ from the technical dimension, 
$X=8.06$ from the cognitive dimension, $X=6.94$ points from the social dimension and $X=64.67$ point from the total. When the score that Turkish teachers took from the total of the scale $(X=64.67)$ is compared to the highest score that can be obtained from the scale (85), it is revealed that Turkish teachers' digital literacy levels are high. It is seen that the skewness and kurtosis values of the scale indicate normal distribution. These values must be between -2 and +2 to indicate normal distribution (George \& Mallerry, 2003). In addition, the Cronbach's Alpha reliability coefficient of the scale was calculated 0.935. Considering the fact that a scale's reliability coefficient being higher than 0.70 means that it is reliable, it can be stated that the reliability of this scale is quite high.

In order to examine the digital literacy status of Turkish teachers according to gender variable, a t-test was conducted and the analysis performed is indicated in Table 2.

Table 2. Average of Turkish Teachers' Digital Literacy Total Scores According to Gender Variable

\begin{tabular}{lllllll}
\hline & Gender & $\mathbf{n}$ & Avera & Ss & $\mathbf{t}$ & $\mathbf{P}$ \\
\hline \multirow{2}{*}{ Attitude } & Female & 80 & 27,66 & 4,917 & \multirow{2}{*}{, 330} & \multirow{2}{*}{185} \\
& Male & 108 & 26,57 & 5,972 & & \\
Technical & Female & 80 & 21,96 & 5,211 & $-1,647$ &, 101 \\
& Male & 108 & 23,13 & 4,481 & & \\
Cognitive & Female & 80 & 8,25 & 1,419 & \multirow{2}{*}{, 474} &, 142 \\
& Male & 108 & 7,92 & 1,613 & & \\
Social & Female & 80 & 6,71 & 1,911 & & \multirow{2}{*}{129} \\
Digital Literacy & Fale & 108 & 7,11 & 1,665 & & \\
Total Score & Male & 108 & 64,73 & 11,885 &,- 082 &, 934 \\
\hline
\end{tabular}

When Table 2 was examined, it was determined that there was no significant difference in the digital literacy status of Turkish teachers according to the gender variable ( $t=-, 082 p=, 934 p>0.05)$. In addition, no significant difference was determined in the sub-dimensions of the digital literacy scale that were attitude $(\mathrm{t}=$ $1,330 \mathrm{p}=, 185 \mathrm{p}>0.05)$; technical $(\mathrm{t}=-1.647 \mathrm{p}=, 101 \mathrm{p}>0.05)$; cognitive $(\mathrm{t}=1.474 \mathrm{p}=, 142 \mathrm{p}>0.05)$ and social $(\mathrm{t}=$ $-1.524 \mathrm{p}=, 129 \mathrm{p}>0.05)$ according to the gender variable.

While the average scores obtained by female teachers from the digital literacy scale were $X=64.59$, the average score of male teachers was determined as $X=64.73$. This situation indicates that the digital literacy levels of male and female teachers are close to each other.

Kruskal-Wallis analysis was conducted to find out whether the digital literacy total scores of Turkish Teachers have a relationship with the age variable. At the same time, a Games-Howell test, one of the Post Hoc tests, was conducted to understand the significance relationship between Turkish teachers' digital literacy and age groups.

Table 3. Relationship Between Turkish Teachers' Digital Literacy Total Scores and Age Variable

\begin{tabular}{|c|c|c|c|c|c|c|c|}
\hline \multirow{2}{*}{ 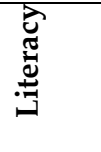 } & Age & $\mathbf{n}$ & $\begin{array}{l}\text { Average } \\
\text { Rank }\end{array}$ & $x^{2}$ & sd & p & Significance \\
\hline & (1) 23-29 years & 31 & 109,56 & & & & \\
\hline \multirow{4}{*}{ 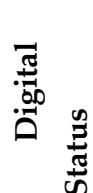 } & (2) 30-36 years & 72 & 103,26 & & & & \\
\hline & (3) $37-43$ years & 52 & 95,52 & 18,837 & 4 & ,001 & $1-5 ; 2-5$ \\
\hline & (4) $44-50$ years & 22 & 66,30 & & & & \\
\hline & (5) 51 years and more & 11 & 46,27 & & & & \\
\hline
\end{tabular}


When Table 3 is examined, it can be seen that there is a significant relationship between the digital literacy status of Turkish teachers and the age variable $(p<.0 .05 p=, 001)$. When the relationship between Turkish teachers' digital literacy status and age group is examined it can be observed that teachers' digital literacy levels are higher than those between the ages of 23-29 than those between the ages of 44-50 and those aged 51 and over; and also those between the ages of 30-36 are higher than those aged 51 and over. This situation reveals that as the average age of Turkish teachers increases, their digital literacy levels decrease.

Kruskal-Wallis analysis was conducted to understand whether there is a relationship between the digital literacy status of Turkish teachers and their years of service in the profession. In addition, the GamesHowell test, one of the Post Hoc tests, was conducted to understand the relationship between the digital literacy of Turkish teachers and the groups that belong to their years of service.

Table 4. The Relationship Between Turkish Teachers' Total Digital Literacy Scores and Years of Service in their Profession

\begin{tabular}{|c|c|c|c|c|c|c|c|}
\hline \multirow{2}{*}{ 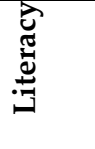 } & $\begin{array}{l}\text { Years of Service in } \\
\text { Profession }\end{array}$ & $\mathbf{n}$ & $\begin{array}{l}\text { Average } \\
\text { Rank }\end{array}$ & $x^{2}$ & sd & $\mathbf{p}$ & Significance \\
\hline & (1) 1-6 years & 25 & 99,20 & & & & \\
\hline \multirow{4}{*}{ 䓢 } & (2) 7-12 years & 63 & 103,72 & & & & \\
\hline & (3) $13-18$ years & 42 & 112,48 & 22,767 & 4 & ,000 & $1-5 ; 2-5$ \\
\hline & (4) $19-24$ years & 33 & 81,65 & & & & $3-5$ \\
\hline & (5) 25 years and more & 25 & 53,32 & & & & \\
\hline
\end{tabular}

When Table 4 is examined, it can be seen that there is a significant relationship between the digital literacy status of Turkish teachers and the years of service in their profession $(p<.0 .05 p=.000)$. When the relationship between the digital literacy status of Turkish teachers and the groups that belong to the years of service in their profession is examined, it is observed that the digital literacy levels of the teachers who have 1-6 years of service are higher than those with 25 years and more; those who have 7-12 years of service are higher than those with 25 years or more; and also those with 13-18 years of service are higher than those with 25 years or more. This indicates that as the years of service of Turkish teachers increase, their digital literacy levels decrease.

The results of the one-way variance (ANOVA) analysis conducted in order to understand whether the digital literacy status of Turkish teachers differs according to their technology usage levels is given in Table 5 .

Table 5. ANOVA Results Indicating the Relationship Between Turkish Teachers' Digital Literacy Total Scores and Technology Usage Levels

\begin{tabular}{|c|c|c|c|c|c|c|c|c|c|c|}
\hline 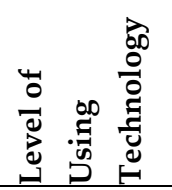 & $\mathbf{n}$ & $X$ & Ss & 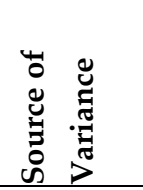 & KT & Sd & KO & $\mathbf{F}$ & $\mathbf{p}$ & \\
\hline \multirow[t]{2}{*}{ (1) Weak } & 11 & 42,36 & 11,630 & Between & 10324,934 & 3 & 3441,645 & & & 1-2; \\
\hline & & & & Groups & & & & & & 1-3; \\
\hline (2) Mid & 61 & 59,33 & 9,239 & In-group & 15814,620 & 184 & 85,949 & 40,043 & ,000 & 1-4; \\
\hline (3) Good & 95 & 68,84 & 8,410 & Total & 26139,553 & 187 & & & & $2-3$ \\
\hline Very & 21 & 73,00 & 11,602 & & & & & & & $2-4$ \\
\hline \multicolumn{11}{|l|}{ Good } \\
\hline Total & 188 & 64,67 & 11,823 & & & & & & & \\
\hline
\end{tabular}

When Table 5 is examined, it can be seen that there is a significant difference between the digital literacy and technology usage levels of Turkish teachers $(F=40,043 \mathrm{p}<0,05)$. According to the Scheffe test results, 
which was conducted to determine between which levels the digital literacy status of teachers differ, it was determined that those whose technology usage levels were very good $(X=73.00)$ were higher than weak $(X=$ 42.36) and medium $(X=59.33)$; those who were good $(X=68.84)$ were higher than middle $(X=59.33)$ and weak $(X=42.36)$; and medium $(X=59.33)$ ones were higher than the weak ones $(X=42.36)$.

The results of the one-way variance (ANOVA) analysis conducted in order to understand whether the digital literacy status of Turkish teachers differs according to the duration of internet usage is indicated in Table 6.

Table 6. ANOVA Results Indicating the Relationship Between Turkish Teachers' Digital Literacy Total Scores and Internet Usage Level

\begin{tabular}{|c|c|c|c|c|c|c|c|c|c|c|}
\hline 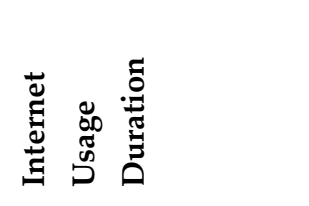 & $\mathbf{n}$ & $\mathrm{x}$ & Ss & 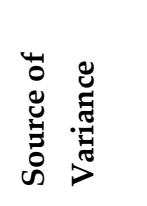 & KT & Sd & KO & F & p & 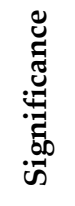 \\
\hline Less than 1hour (1) & 9 & 51,33 & 14,534 & $\begin{array}{l}\text { Between } \\
\text { Groups }\end{array}$ & 4561,146 & 4 & 1140,287 & & & \\
\hline 1-2 hours (2) & 42 & 58,93 & 11,754 & In-group & 21578,407 & 183 & 117,915 & & & \\
\hline 3-4 hours (3) & 69 & 65,26 & 10,465 & Total & 26139,553 & 187 & & & & 1-3; \\
\hline $4-5$ hours $(4)$ & 45 & 68,82 & 10,663 & & & & & & & 1-4; \\
\hline 5 hours and more (5) & 23 & 70,48 & 8,979 & & & & & 9,670 & ,000 & 1-5; \\
\hline Total & 188 & & & & & & & & & $\begin{array}{l}2-4 ; \\
2-5 ;\end{array}$ \\
\hline
\end{tabular}

When Table 6 is examined, it can be seen that there is a significant difference between the digital literacy status of Turkish teachers and the duration of internet use ( $F=9.670 \mathrm{p}<0.05)$. According to the results of the Scheffe test conducted in order to determine among which levels the digital literacy of teachers differ, it was determined that those who use the internet for 5 hours or more $(X=70.48)$ and $4-5$ hours $(X=68.82)$ were higher than 1 hour $(X=51.33)$ and 1-2 hours $(X=58.93)$; and those who use 3-4 hours $(X=65.26)$ were higher than those who use less than 1 hour $(X=51.33)$.

In order to understand whether the digital literacy status of Turkish teachers differs according to their use of distance education platforms, a t-test was performed and the analysis carried out is indicated in Table 7.

Table 7. Average of Digital Literacy Status of Turkish Teachers According to the Use of Distance Education Platforms

\begin{tabular}{|c|c|c|c|c|c|c|}
\hline & & $\mathbf{n}$ & Mean & Ss & $\mathbf{t}$ & $\mathbf{P}$ \\
\hline \multirow{2}{*}{ Attitude } & Yes & 172 & 27,47 & 5,446 & \multirow{2}{*}{3,566} & \multirow{2}{*}{,000 } \\
\hline & No & 16 & 22,44 & 4,761 & & \\
\hline \multirow{2}{*}{ Technique } & Yes & 172 & 23,04 & 4,518 & \multirow{2}{*}{3,943} & \multirow{2}{*}{,000 } \\
\hline & No & 16 & 18,25 & 5,939 & & \\
\hline \multirow{2}{*}{ Cognitive } & Yes & 172 & 8,16 & 1,516 & \multirow{2}{*}{2,936} & \multirow{2}{*}{,004 } \\
\hline & No & 16 & 7,00 & 1,414 & & \\
\hline \multirow{2}{*}{ Social } & Yes & 172 & 7,09 & 1,714 & \multirow{2}{*}{3,976} & \multirow{2}{*}{,000 } \\
\hline & No & 16 & 5,31 & 1,702 & & \\
\hline Digital Literacy & Yes & 172 & 65,76 & 11,335 & \multirow{2}{*}{4,318} & \multirow{2}{*}{, 000 } \\
\hline Total Score & No & 16 & 53,00 & 10,912 & & \\
\hline
\end{tabular}

When Table 7 is examined, it can be seen that there is a significant difference in digital literacy status of Turkish teachers according to their use of distance education platforms $(t=4.318 p=.000 p<0.05)$. Also it was 
determined that there is a significant difference in the attitude $(t=3,566 p=, 000 p<0,05)$; technical $(t=3.943 p$ $=, 000 \mathrm{p}<0.05)$; cognitive $(\mathrm{t}=2.936 \mathrm{p}=.004 \mathrm{p}<0.05)$ and social $(\mathrm{t}=3.976 \mathrm{p}=, 000 \mathrm{p}<0.05)$ sub-dimensions of the digital literacy scale according to the use of distance education platforms.

While the average scores of Turkish teachers, who use distance education platforms, from the digital literacy scale are $X=65,76$, the average score of teachers who do not use distance education platforms was found $X=53,00$. This situation indicates that the digital literacy levels of teachers who use distance education platforms are higher than those who do not use.

In order to understand whether the digital literacy status of Turkish teachers differs according to the use of social media in the distance education process, a t-test was performed and the analysis carried out is indicated in Table 8.

Table 8. Average of Turkish Teachers' Digital Literacy Status by Social Media Usage in the Distance Education Process

\begin{tabular}{lllllll}
\hline & & $\mathbf{n}$ & Mean & Ss & t & P \\
\hline \multirow{2}{*}{ Attitude } & Yes & 167 & 27,49 & 5,492 & \multirow{2}{*}{, 190} &, 002 \\
Technical & No & 21 & 23,48 & 4,864 & & \\
& Yes & 167 & 22,95 & 4,649 & & \\
Cognitive & No & 21 & 20,10 & 5,549 & 2,596 &, 010 \\
& Yes & 167 & 8,09 & 1,536 & \multirow{2}{*}{, 786} & \\
Social & No & 21 & 7,81 & 1,569 & & \\
& Yes & 167 & 7,00 & 1,722 & \multirow{2}{*}{, 273} &, 205 \\
Digital Literacy & No & 21 & 6,48 & 2,182 & & \\
Total Score & Yes & 167 & 65,53 & 11,552 & 2,855 &, 005 \\
\hline
\end{tabular}

According to Table 8, it was determined that there is a significant difference in digital literacy status of Turkish teachers compared to their use of social media in the distance education process $(t=2,855 \mathrm{p}=.005 \mathrm{p}$ $<0.05)$. In addition, a significant difference was found in attitude $(t=3.190 p=.002 p<0.05)$ and technical $(t=-$ $2.596 p=, 010 p<0.05)$ sub-dimensions of the digital literacy scale. However, it was observed that there was no significant difference in the cognitive $(t=, 786 p=, 433 p>0.05)$ and social $(t=1.273 p=, 205 p>0.05)$ subdimensions of the scale.

While the average score of Turkish teachers who use social media in the distance education process from the digital literacy scale was $X=65.53$, the average score of teachers who do not use it was determined as $X=53.86$. This indicates that the digital literacy levels of teachers who use social media in the distance education process are higher than those who do not use.

\section{Conclusion and Discussion}

The following results were obtained in this study, which aims to determine the digital literacy levels of Turkish teachers and to examine them in terms of several variables.

According to the results of the study, the average of the scores Turkish teachers took from the total of the digital literacy scale was determined as $X=64.67$. This situation means that Turkish teachers' digital literacy levels are high. When the average scores that Turkish teachers took from the sub-dimensions of the scale, the attitude dimension $X=27.04$; technical dimension $X=22.63$; $\operatorname{cognitive}$ dimension $X=8,06$; and social dimension was calculated as $X=6.94$. These results mean that Turkish teachers' attitudes towards digital literacy, technical knowledge, cognitive and social skills are sufficient. Many studies in the literature coincide with the results of this study. In the research of Korkmaz (2020) it was determined that the digital literacy levels of classroom teachers were at a high level. Arslan (2019), who conducted research on 345 teachers 
working in primary and secondary schools, reached the same result in a study. In the study of Öçal (2017) it was concluded that primary school teachers feel themselves at a very sufficient level in terms of digital literacy. In Sarıkaya's (2019) research, which was conducted with Turkish teacher candidates, it was concluded that the participants had a high level of digital literacy skills. Similar results were obtained in many studies regarding teacher candidates (Özoğlu, 2019; Özerbaş \& Kuralbayeva, 2018; Kozan, 2018; Üstündağ, Güneş \& Bahçivan, 2017; İşçioğlu \& Kocakuşak, 2012).

In the t-test results, it was determined that there was no significant difference in digital literacy levels of Turkish teachers according to the gender variable $(t=-, 082 p=, 934 p>0.05)$. It was observed that the digital literacy levels of male and female teachers were very close to each other. Similar results were obtained in some studies conducted regarding teachers and teacher candidates in the literature (Arslan, 2019; Sarıkaya, 2019; Kazu \& Erten, 2014). However, in some studies (Korkmaz, 2020; Özerbaş \& Kuralbayeva, 2018; Yeşildal, 2018; Çetin, 2016; Kıyıc1, 2008), it was found that the digital literacy level varies according to the gender variable, and the digital literacy level of men was higher than women.

When the relationship between the digital literacy status of teachers and the age variable was examined, significant differences were determined $(p<.0 .05 p=, 001)$. It was determined that as the average age of Turkish teachers increases, their digital literacy levels decrease. Korkmaz (2020) studying with classroom teachers on digital literacy, Öçal (2017) studying with primary school teachers, and Yeşildal (2018) studying with many different age groups found a similar result between age and digital literacy, and that the digital literacy level decreased with the increase of age. This situation can be explained by the fact that young people get to know the rapidly developing and spreading technological opportunities earlier than the older individuals and use digital media more widely.

It was found that there is a significant relationship between the digital literacy status of Turkish teachers and their years of service in the profession $(\mathrm{p}<.0 .05 \mathrm{p}=, 001)$. It was observed that as the years of service of teachers in the profession increased, their digital literacy levels decreased. In their studies Korkmaz (2020), Arslan (2019) and Öçal (2017) also found that professional service is a distinctive variable on teachers' perceptions of digital literacy competence, and the level of digital literacy decreases with increasing years of service.

It is seen that there is a significant difference between the digital literacy status of Turkish teachers and their level of using technology ( $F=40,043 p<0,05)$. It was observed that those who use technology very well and well have higher digital literacy levels than weak ones. In Sarıkaya's (2019) study, which was carried out with Turkish teacher candidates, a similar result was obtained.

In the research, it was concluded that the digital literacy levels of teachers who use the internet more are significantly higher. Arslan (2019) found a significant difference between the digital literacy levels of teachers and their daily internet usage duration. It was also observed that the more time teachers spend on the internet daily, their level of digital literacy increases. According to the daily internet usage duration variable, Çetin (2016) reached the same result in a study. On the other hand, Özerbaş and Kuralbayeva (2018) found that having an internet connection is an effective variable on pre-service teachers' views on digital literacy, and that pre-service teachers with constant internet connection feel more competent in terms of digital literacy. Contrary to these results, Göldağ and Kanat (2018) concluded in their study that there is no relationship between students' internet usage duration and their digital literacy level. They explained this situation on the grounds that students do not use websites consciously, and they use them for entertainment and chat purposes.

In this study conducted during the COVID-19 epidemic, it was also examined whether Turkish teachers' use of distance education platforms and social media had an impact on their digital literacy. As a result of this 
examination, it was concluded that Turkish teachers who use distance education platforms effectively have higher digital literacy levels than Turkish teachers who use the platforms less $(t=4.318 p=.000 p<0.05)$. In addition, it was determined that Turkish teachers who use social media more effectively in the distance education process have higher digital literacy $(t=2,855 p=.005 p<0.05)$. Sarıkaya (2019) also found a significant relationship between having a social media account and digital literacy level in a study. He concluded that the digital literacy levels of Turkish teacher candidates who own social media were higher than those who do not have social media account. Contrary to these results, Göldağ and Kanat (2018) concluded that there is no relationship between social media ownership and digital literacy in their study. 


\section{REFERENCES}

Arslan, S. (2019). Investigation of digital literacy levels of teachers working in primary and secondary schools in terms of various variables (Unpublished master's thesis), Sakarya University, Sakarya.

Campbell, M. \& Akbulut, Y. (2019). Çocuklar ve gençlerin dijital yaşamla mücadeleleri. H. Ferhan Odabaşı (Ed.), Dijital yaşamda çocuk içinde (s. 89-116). Ankara: Pegem Akademi.

Creswell, J. W. (2017). Araştırma deseni nitel, nicel ve karma yöntem yaklaşımları. (S. B. Demir, Trans, Ed.). Ankara: Eğiten Kitap.

Çetin, O. (2016). Pedagojik formasyon programı ile lisans eğitimi fen bilimleri öğretmen adaylarının dijital okuryazarlık düzeylerinin incelenmesi. Erzincan Üniversitesi Ĕ̆itim Fakültesi Dergisi, 18 (2), 658-685.

Dowdall, C. (2009). Masters and critics: Children as producers of online digital texts. V. Carrington \& M. Robinson (Eds.), Dijital literacies: Social learning and classroom practices in (pp. 43-61). London: Sage Publication.

Erol, S. (2020). Dinlemeye yönelik eğitim ortamları. M. Nuri Kardaş (Ed.) Dinleme eğitimi içinde (s. 221-242). Ankara: Pegem Akademi.

Ferrari, A. (2013). DIGCOMP: A Framework for Developing and Understanding Digital Competence in Europe, Retrieved from https://publications.jrc.ec.europa.eu/repository/bitstream/JRC83167/lb-na26035-enn.pdf

George, D. \& Mallery, P. (2013). IBM SPSS statistics 23 step by step: A simple guide and reference. Routledge.

Gökbulut, B. (2019). Teknolojik gelişmeler ışığında ulusal ve uluslararası öğretmen yeterlikleri ve teknopedagojik alan bilgisi. Ali Arslan (Ed.), Eğitimde güncel konular ve yeni yaklaşımlar içinde (s. 145-164). Ankara: Nobel Akademi.

Göldağ, B. \& Kanat, S. (2018). Güzel Sanatlar Eğitimi Alan Öğrencilerin Dijital Okuryazarlık Durumları. Jass Studies-The Journal of Academic Social Science Studies, 70, 77-92.

Hague, C. \& Payton, S. (2010). Digital literacy across the curriculum: A Futurelab handbook, Retrieved from https://www.nfer.ac.uk/publications/FUTL06/FUTL06.pdf

Hamutoğlu, N. B., Güngören, Ö. C., Uyanık G. K. \& Erdoğan, D. G. (2017). Dijital okuryazarlık ölçeği: Türkçeye uyarlama çalışması. Ege Ĕ̆itim Dergisi, 18, 408- 429.

Heitin, L. (2016). What is digital literacy? Digital Literacy: An Evolving Definition, Retrieved from https://online.tarleton.edu/Home_files/EDUC_3320/Educator_as_Citizen/What\%20Is\%20Digital\%20Lit eracy_\%20-\%20Education\%20Week.pdf

İşçioğlu, E. \& Kocakuşak, S. (2012). İlköğretim sınıf öğretmeni adaylarının sayısal okuryazarlık düzeyleri ve teknoloji algıları. Hacettepe Üniversitesi Eğitim Fakültesi Dergisi, 2, 15-24.

Johnson, G. M. (2008). Cognitive processing differences between frequent and infrequent Internet users. Computers in Human Behavior, 24, 2094-2106.

Johnson, G. M. (2010). Young children's Internet use at home and school: Patterns and profiles. Journal of Early Childhood Research, 8, 282-293.

Jones-Kavalier, B. \& Flannigan, S. (2006). Connecting the digital dots: Literacy of the 21st century. Educause Quarterly, 29(2), 1-3. 
Karasar, N. (2018). Bilimsel araştırma yöntemi: Kavramlar, ilkeler, teknikler. Ankara: Nobel Akademi Yayıncılık.

Kazakoff, E. R. (2014). Toward a theory-predicated definiton of digital literacy for early child-hood. Journal of Youth Development, 9(1), 41-58.

Kazu, İ. Y. \& Erten, P. (2014). Öğretmen adaylarının sayısal yetkinlik düzeyleri. Bartın Üniversitesi Ĕgitim Fakültesi Dergisi, 3(2), 132-152.

Kıyıc1, M. (2008). Identifying digital literacy level of teachers candidates (Unpublished doctoral thesis), Anadolu University, Eskişehir.

Korkmaz, M. (2020). Determining digital literacy levels of primary school teachers (Unpublished master's thesis), Eskişehir Osmangazi University, Eskişehir.

Kozan, M. (2018). Examination of department of computer education and instructional technology teacher candidates'

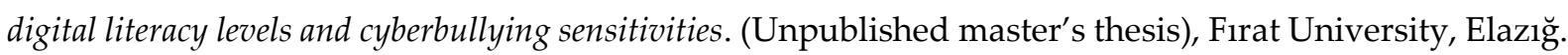

Kula, A. \& Avcı, Ü. (2019). Eğitimde dijital dönüşüm ve büyük veri. Aytekin İşman, H. Ferhan Odabaşı \& Buket Akkoyunlu (Ed.), Eğitim teknolojileri okumaları 2019 içinde (s. 261-285). Ankara: Pegem Akademi.

Kurt, A. A. \& Orhan Göksun, D. (2020). Teknoloji ve yeni okuryazarlıklar. A. A. Kurt (Ed.), Öğretim teknolojilerinin temelleri içinde (s. 75-93). Ankara: Nobel Akademi.

Martin, A. \& Grudziecki, J. (2006). DigEuLit: concepts and tools for digital literacy development. Innovation in Teaching and Learning in Information and Computer Sciences, 5(4), 248-267.

Menzi Çetin, N. \& Akkoyunlu, B. (2017). Dijital okuryazarlık ve bilimsel iletişim. H. Ferhan Odabaşı, Buket Akkoyunlu \& Aytekin İşman (Ed.), Eğitim teknolojileri okumaları 2017 içinde (s. 109-124). Ankara: TOJET.

$\mathrm{Ng}$, W. (2012). Can we teach digital natives digital literacy? Computer E Education, 59(3), 1065-1078.

Öçal, F. N. (2017). Perceptions of digital literacy competence related to primary school teacher and parents themselves with their children (Unpublished master's thesis), Gazi University, Ankara.

Özerbaş, M. \& Kuralbayeva, A. (2018). Türkiye ve Kazakistan öğretmen adaylarının dijital okuryazarlık düzeylerinin değerlendirilmesi. Muğla Sıtkı Koçman Üniversitesi Ĕ̆itim Fakültesi Dergisi, 5(1), 16-25.

Özoğlu, C. (2019). Analysis of the relationship between the lifelong learning tendencies and digital literacy of teacher candidates (Anadolu University education faculty sample) (Unpublished master's thesis), Anadolu University, Eskişehir.

Parlak, B. (2017). Dijital çağda eğitim: Olanaklar ve uygulamalar üzerine bir analiz. Süleyman Demirel Üniversitesi İktisadi ve İdari Bilimler Fakültesi Dergisi, 22(15), 1741-1759.

Pilgrim, J. \& Martinez, E. E. (2013). Defining literacy in the 21st century: A guide to terminology and skills. Texas Journal of Literacy Education, 1(1), 60-69.

Sarıkaya, B. (2019). Türkçe öğretmeni adaylarının dijital okuryazarlık durumlarının çeşitli değişkenler açısından değerlendirilmesi. Uluslararası Sosyal Araştırmalar Dergisi, 62, 1098-1107.

Selwyn, N. \& Odabaşı, H. F. (2019). Çocuklar ve gençlerin dijital yaşamla mücadeleleri. H. Ferhan Odabaşı (Ed.), Dijital yaşamda çocuk içinde (s.1-18). Ankara: Pegem Akademi. 
Soylu Yılmaz, M. \& Akkoyunlu, B. (2019). Dijital yazma ortamları ve yazmaya ilişkin inançlar. Aytekin İşman, H. Ferhan Odabaşı \& Buket Akkoyunlu (Ed.), Ĕ̆itim teknolojileri okumaları 2019 içinde (s. 151-167). Ankara: Pegem Akademi.

Spears, B. A., Kofoed, J., Bartolo, M. G., Palermiti, A. L., \& Costabile, A. (2012). Positive uses of social networking sites: Youth voice perspectives. A. Costabile, \& B. A. Spears (Eds.), The impact of technology on relationships in educational settings in (pp. 7-21). New York, NY: Routledge.

Taşkıran, A. (2017). Dijital çağda yükseköğretim. Journal Of Open Education Practice and Research, 3(1), 96-109.

Üstündağ, M., Güneş, E. \& Bahçivan, E. (2017). Dijital okuryazarlık ölçeğinin Türkçeye uyarlanması ve fen bilgisi öğretmen adaylarının dijital okuryazarlık durumları. Journal of Education and Future, 12, 19-29.

Yeşildal, M. (2018). The relationship between digital literacy and health literacy in adult individuals: The case of Konya (Unpublished master's thesis), Necmettin Erbakan University, Konya.

Yıldırım, A. \& Şimşek, H. (2008). Sosyal bilimlerde nitel araştırma yöntemleri. Ankara: Seçkin Yayıncılık. 